\title{
Determination of In vitro Anti-inflammatory Activity of Marine Microalgae: Nannochloropsis
} sp.

\author{
P.K. Deepa ${ }^{1, *}$, A. Subramanian ${ }^{1}$ and W.A. Manjusha ${ }^{2}$ \\ 'Department of Zoology, S.T. Hindu College Nagercoil, Affiliated to Manonmaniam \\ Sundaranar University, Tirunelveli, 627012, India \\ 2Department of Biotechnology, Malankara Catholic College, Mariagiri, Affiliated to \\ Manonmaniam Sundaranar University, Tirunelveli, 627012, India
}

\begin{abstract}
Article Type: Article
Article Citation: Deepa PK, Subramanian A, Manjusha WA. Determination of in vitro antiinflammatory activity of marine microalgae: Nannochloropsis sp. Indian Journal of Science and Technology. 2020; 13(08),871-882.D0l:10.17485/ijst/2020/ v013i08/149758
\end{abstract}

Received date: December 20, 2019

Accepted date: February 8, 2020

*Author for correspondence: P.K. Deepa \deepabiochems@ gmail.com Department of Zoology, S.T. Hindu College Nagercoil, Affiliated to Manonmaniam Sundaranar University, Tirunelveli, 627012, India

\begin{abstract}
Objectives: To determine the in vitro anti-inflammatory activity of solvent extract of the marine microalgae, Nannochloropsis sp. Materials and methods: The preliminary assays for antiinflammatory activity such as protein denaturation inhibition and membrane stabilization were evaluated in the various solvent extracts (petroleum ether, aqueous, isopropanol, methanol, ethyl acetate) of the microalgae, Nannochloropsis sp. and in vitro antiinflammatory effect was determined in ethyl acetate extract against murine macrophage (RAW 264.7) cells. The compounds present in the extract were analyzed through GCMS. Results: The ethyl acetate extract exhibited good protection against protein denaturation at an inhibition rate of $72.66 \pm 0.46 \%$ and provides significant membrane stabilization by inhibiting hemolysis by $92.02 \pm 0.10$ $\%$. The in vitro anti-inflammatory activity was found to be dose dependent by inhibiting the inflammatory mediators such as COX $(62.08 \pm 0.035 \%)$, LOX $(65.84 \pm 0.19 \%)$ and also reduced production of the MPO $(0.000797 \pm 0.00003 \mathrm{lU} / \mathrm{ml})$ and iNOS $(90.44 \pm 0.19 \%)$ thereby cellular nitrite level to $342.54 \pm 0.49 \mu \mathrm{g} / \mathrm{ml}$. The GCMS analysis for bioactive compounds showed a total of 16 compounds in which phenols and lipids are the major components. Application: The result suggests that the microalgae contain potential antiinflammatory compounds which can be explored in therapeutics against inflammation induced diseases.
\end{abstract}

Keywords: Nannochloropsis sp., Microalgae, Anti-inflammatory, Membrane Stabilization.

\section{Introduction}

Inflammation is a defensive mechanism of an organism against local injury and infections, which can progress to painful or chronically harmful diseases requiring pharmacological 
treatment [1]. Various immune cells such as macrophages, neutrophils, and lymphocytes are activated during inflammation [2]. It is characterized by redness, pain, heat, swelling, and loss of function in the injured area. Increased production of free radicals during inflammation causes an imbalance between the oxidizing molecules and the antioxidant system of the body. This oxidative stress leads to damage in the cellular components [3]. Eicosanoids and cytokines have significant role differentiation, development, and regulation of immune cells and are mediators of immune response [4]. Inflammation can progress to painful or chronically harmful diseases such as psoriasis, rheumatoid arthritis, and colitis, which can cause death and disability in the world [5]. Protein denaturation is one of the causes of inflammation [6]. One of the strategies to regulate inflammation is to inhibit the release of lysosomal constituents [7].

Marine organisms are one of the interested areas in research, especially in microalgae for the past decades as they produce pharmacologically active metabolites. Microalgal molecules such as carotenoids, phycobilins, polyunsaturated fatty acids, proteins, polysaccharides, vitamins, and sterols possess several health benefits and therefore are used in many sectors such as nutraceutical, pharmaceutical, and functional foods [8]. The microalgae, Nannochloropsis sp. are used in aquaculture as they are rich in omega-3 fatty acids [9]. They are the excellent source of eicosapentanoic acid (EPA). EPA and docosahexaenoic acid (DHA) were found to have positive effects on, anti-inflammatory activity, prevention of heart disease brain vision health and development [10]. The current work aimed at determining anti-inflammatory property of the marine microalgae, Nannochloropsis sp. and identify the chemical constituents by GC-MS analysis.

\section{Materials and Methods}

\subsection{Microalgae Extract Preparation Using Different Organic Solvents}

Marine microalgae, Nannochloropsis sp. were collected from the Centre for Marine Fisheries Research Institute (CMFRI) Tuticorin, Tamilnadu, India. The microalgae were sub-cultured in Conway medium and maintained as a pure culture. The microalgae cells were obtained by centrifugation. The pellet was collected and air dried under room temperature to get a fine powder. Dried microalgae cells of $10 \mathrm{~g}$ were extracted in $100 \mathrm{ml}$ of different organic solvents specifically methanol, aqueous, isopropanol, petroleum ether, and ethyl acetate and was kept at $4{ }^{\circ} \mathrm{C}$ for 7 days with occasional shaking. It was then filtered using Whatman no. 1 filter paper. The filtrate was kept at room temperature to evaporate excess solvent. The concentrated filtrate was used for the further experiments.

\subsection{Protein Denaturation Inhibition Assay}

The assay was done by the method followed by [11]. To $0.1 \mathrm{ml}$ of various solvent extract added $0.45 \mathrm{ml}$ bovine serum albumin and incubated at $37^{\circ} \mathrm{C}$ for $30 \mathrm{~min} .2 .5 \mathrm{ml}$ phosphate buffer saline ( $\mathrm{pH}$ 6.3) was added to each tube after cooling. Turbidity was measured 
spectrophotometrically at $660 \mathrm{~nm}$. The percentage inhibition of protein denaturation was calculated by the following formula. Salicylic acid was taken as standard drug.

$\%$ of inhibition $=$ Absorbance of control - Absorbance of test/Absorbance of control $\times$ 100

\subsection{Membrane Stabilization Assay}

\subsubsection{Preparation of Red Blood Cells (RBCs) Suspension}

The assay was performed by the method followed by [12]. The fresh whole human blood $(10 \mathrm{ml})$ was collected and transferred in a centrifuge tube containing heparin. The tubes were centrifuged at $3000 \mathrm{rpm}$ for $10 \mathrm{~min}$ and were washed three times with equal volume of normal saline. The volume of blood was measured and reconstituted as $10 \% \mathrm{v} / \mathrm{v}$ suspension with normal saline.

\subsubsection{Heat Induced Hemolysis}

$1 \mathrm{ml}$ of various solvent extracts was added to $1 \mathrm{ml}$ of $10 \%$ RBC suspension. Diclofenac sodium was taken as a standard drug. The reaction mixture was centrifuged and incubated in a water bath at $56{ }^{\circ} \mathrm{C}$ for $30 \mathrm{~min}$. The tubes were cooled and centrifuged at $2500 \mathrm{rpm}$ for $5 \mathrm{~min}$. The absorbance of the supernatants was taken at $560 \mathrm{~nm}$. The experiment was performed in triplicates. The $\%$ of membrane stabilization activity was calculated by the following formula. \% of inhibition = Absorbance of control - Absorbance of test/ Absorbance of control $\times 100$.

\subsection{Determination of In vitro anti-inflammatory Activity}

Murine macrophage cells (RAW 264.7) were initially procured from National Centre for Cell Sciences (NCCS), Pune, India and maintained in Dulbecco's modified Eagles medium (DMEM). The cell line was cultured in DMEM supplemented with $10 \%$ FBS, l-glutamine, sodium bicarbonate and antibiotic solution containing: Penicillin (100 U/ $\mathrm{ml})$, Streptomycin $(100 \mu \mathrm{g} / \mathrm{ml})$, and Amphotericin B $(2.5 \mu \mathrm{g} / \mathrm{ml})$ and were incubated at $37{ }^{\circ} \mathrm{C}$ in a humidified $5 \% \mathrm{CO}_{2}$ incubator. When the cell growth reached up to $60 \%$ confluence, the cells were induced with $1 \mu \mathrm{L}$ lipopolysaccharide (LPS: $1 \mu \mathrm{g} / \mathrm{ml}$ ). Different concentration $(25,50,100 \mu \mathrm{g} / \mathrm{ml})$ of sample solution and diclofenac sodium, a standard anti-inflammatory drug, in varying concentration corresponding to the sample was added to the LPS stimulated cell. After $24 \mathrm{~h}$ of incubation, the anti-inflammatory assays were performed using the cell lysate.

\subsubsection{Cyclooxygenase (COX) Activity}

The COX activity was assayed by [13]. Tris- $\mathrm{HCl}$ buffer ( $\mathrm{pH} 8$ ), glutathione $5 \mathrm{mM} / \mathrm{L}$, and hemoglobin $5 \mathrm{mM} / \mathrm{L}$ was added to $100 \mu \mathrm{l}$ cell lysate and incubated for $1 \mathrm{~min}$ at $25^{\circ} \mathrm{C}$. Arachidonic acid of $200 \mathrm{mM} / \mathrm{L}$ was added to initiate the reaction and incubated for $20 \mathrm{~min}$ 
at $37^{\circ} \mathrm{C}$. The reaction was terminated by the addition of $10 \%$ trichloroacetic acid $(200 \mu \mathrm{L})$ in $1 \mathrm{~N}$ hydrochloric acid. After the centrifugal separation, $200 \mu \mathrm{L}$ of $1 \%$ thiobarbiturate was added and the tubes were boiled for $20 \mathrm{~min}$ and centrifuged for three minutes. COX activity was determined by reading absorbance at $632 \mathrm{~nm}$.

$\%$ of inhibition $=$ Absorbance of control - Absorbance of test/Absorbance of control $\times$ 100

\subsubsection{Lipoxygenase (LOX) Activity}

The determination of LOX activity was done as per [14]. To $50 \mu \mathrm{L}$ of cell lysate, added Tris- $\mathrm{HCl}$ buffer ( $\mathrm{pH} 7.4)$, and sodium linoleate $(200 \mu \mathrm{L})$ to make the reaction mixture (2 $\mathrm{ml}$ final volume). The LOX activity was measured as an increase of absorbance at $234 \mathrm{~nm}$, which reflects the formation of 5-hydroxyeicosatetraenoic acid.

$\%$ of inhibition $=$ Absorbance of control - Absorbance of test $/$ Absorbance of control $\times$ 100

\subsubsection{Myeloperoxidase (MPO) Activity}

The determination of MPO activity was done as per the method described by [15]. Cell lysate was homogenized with $50 \mathrm{mM}$ potassium phosphate buffer and $0.57 \%$ hexadecyl trimethyl ammonium bromide (HTAB). The samples were centrifuged at $2000 \mathrm{~g}$ for $30 \mathrm{~min}$ at $4{ }^{\circ} \mathrm{C}$, and collected the supernatant. The sample containing MPO was activated by the addition of $50 \mathrm{mM}$ phosphate buffer $(\mathrm{pH}$ 6) containing $1.67 \mathrm{mg} / \mathrm{ml}$ guaiacol and $0.0005 \%$ $\mathrm{H}_{2} \mathrm{O}$. The change in absorbance was measured at $460 \mathrm{~nm}$. MPO activity was presented as units per $\mathrm{ml}$ of cell lysate. One unit of MPO activity was defined as that degrading $1 \mu \mathrm{M}$ of peroxide per minute at $25^{\circ} \mathrm{C}$.

\subsubsection{Inducible Nitric Oxide Synthase (iNOS) Activity}

Nitric oxide synthase was determined by the method described by [16]. Cell lysate was homogenized in $2 \mathrm{ml}$ of HEPES buffer. To $0.1 \mathrm{ml}$ of Arginine substrate, $0.1 \mathrm{ml}$ manganese chloride, $0.1 \mathrm{ml} 30 \mu \mathrm{g}$ dithiothreitol (DTT), $0.1 \mathrm{ml} \mathrm{NADPH}, 0.1 \mathrm{ml}$ tetrahydropterin, $0.1 \mathrm{ml}$ oxygenated haemoglobin and $0.1 \mathrm{ml}$ enzyme (sample) was added. Increase in absorbance was recorded at $401 \mathrm{~nm}$.

\subsubsection{Estimation of Cellular Nitrite Levels}

The level of nitrite level was estimated by [17]. The reaction mixture containing $0.5 \mathrm{ml}$ of cell lysate and $0.1 \mathrm{ml}$ of sulphosalicylic acid was vortexed well for $30 \mathrm{~min}$. Centrifuged the samples at $5000 \mathrm{rpm}$ for $15 \mathrm{~min}$ and the protein-free supernatant was used for the estimation of nitrite levels. To $200 \mu \mathrm{l}$ of the supernatant, $30 \mu \mathrm{l}$ of $10 \% \mathrm{NaOH}$ and 300 $\mu \mathrm{l}$ of Tris- $\mathrm{HCl}$ buffer and mixed well. To this, $530 \mu \mathrm{l}$ of Griess reagent was added and incubated in the dark for 10-15 min. The absorbance was measured at $540 \mathrm{~nm}$ against a Griess reagent blank. Sodium nitrite solution was used as the standard. The amount of nitrite present in the samples was estimated from the standard curves obtained. 


\subsection{GC-MS Analysis of Microalgae Extract}

The GC-MS analysis of ethyl acetate extract of Nannochloropsis sp. (EAN) was carried out using GC-MS QP2010 Ultra (Shimadzu) with Rxi-5Sil MS fused-silica capillary column of $30 \mathrm{~m}$ length, $0.25 \mathrm{~mm}$ diameter, and $0.25 \mathrm{~mm}$ film thickness. An electron ionization system with ionization energy of $70 \mathrm{eV}$ was used for analysis. Helium gas (99.99\%) was used as the carrier gas at the constant flow-rate of $1 \mathrm{ml} / \mathrm{min}$. The temperatures of the injector and mass transfer line were set at $250{ }^{\circ} \mathrm{C}$ and $240{ }^{\circ} \mathrm{C}$, respectively. The oven temperature was programmed from $80{ }^{\circ} \mathrm{C}$ to $200{ }^{\circ} \mathrm{C}$ at $3{ }^{\circ} \mathrm{C} / \mathrm{min}$, and finally increased to $260{ }^{\circ} \mathrm{C}$ at $10^{\circ} \mathrm{C} / \mathrm{min}$. Aliquots of $1 \mathrm{ml}$ of the diluted samples were injected in split mode with a split ratio of 1:10 and with a mass scan range of 45-900 AMU. The total running time of the GC-MS analysis was $51 \mathrm{~min}$.

\subsection{Statistical Analysis}

The data were analyzed and expressed as means \pm SD. The EC50 values were calculated from linear regression analysis.

\section{Result}

\subsection{Protein Denaturation Inhibition Assay}

The various solvent extracts of Nannochloropsis sp. at $500 \mu \mathrm{g} / \mathrm{ml}$ concentration were evaluated for protein denaturation inhibition activity and is shown in Figure 1. EAN exhibited highest protection against protein denaturation of about $72.66 \pm 0.46 \%$ inhibition among the various solvent extracts which was followed by methanol and isopropanol, petroleum ether and aqueous extract. The extracts were compared with salicylic which showed an inhibition of about $96.13 \pm 0.23 \%$. All experiments were performed in triplicates and the results were expressed as mean \pm SD.

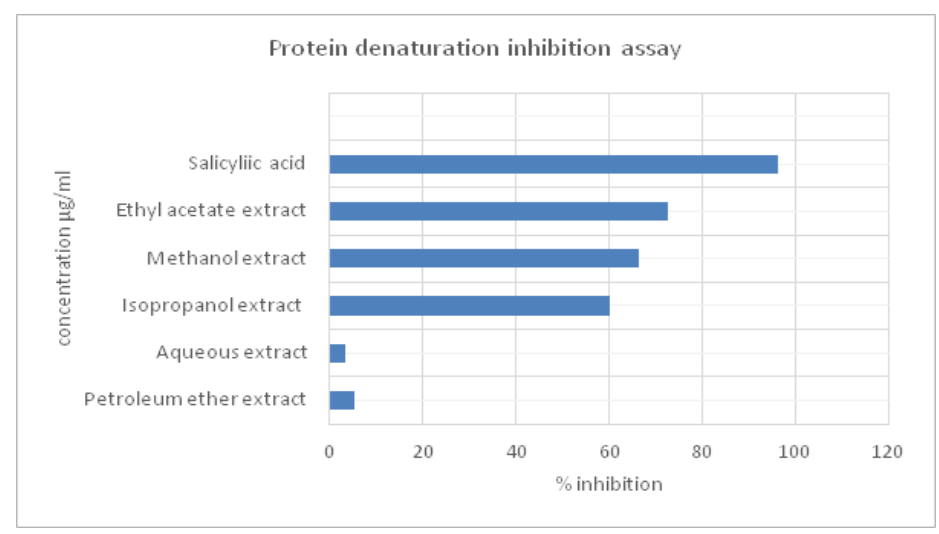

FIGURE 1. Protein denaturation inhibition assay. 


\subsection{Membrane Stabilization Assay}

One of the well-known causes of inflammation is membrane disruption. Figure 2 shows the membrane stabilization activity of various extracts of Nannochloropsis sp. at a concentration of $500 \mu \mathrm{g} / \mathrm{ml}$. The highest activity was noticed in EAN with an inhibition of hemolysis at $92.02 \pm 0.10 \%$, which was followed by methanol, isopropanol, aqueous extract, and least activity was seen in petroleum ether extract. The activity of various extract was compared with the control drug, diclofenac sodium which showed an inhibition of membrane disruption of $96.37 \pm 0.26 \%$.

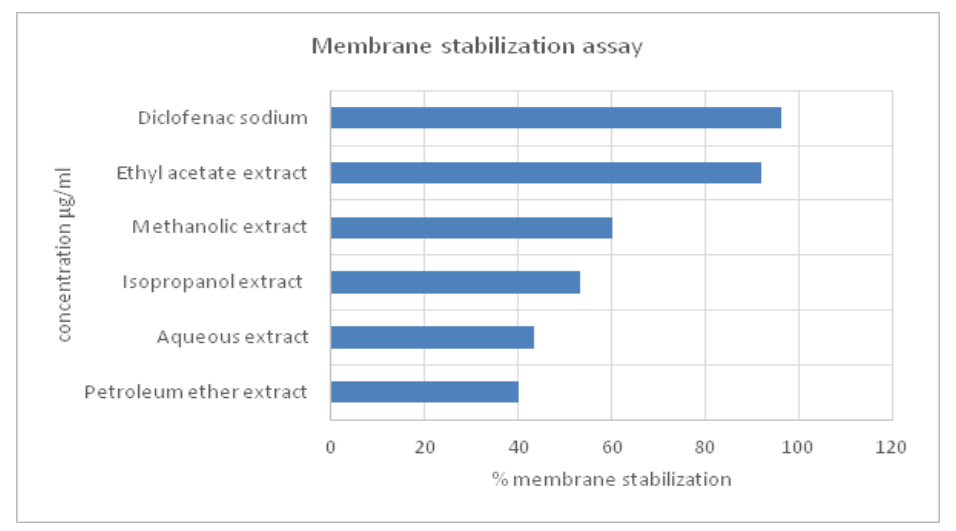

FIGURE 2. Membrane stabilization assay.

\subsection{Determination of In vitro Anti-inflammatory Activity}

\subsubsection{COX Inhibitory Activity}

Cox is the enzyme which produces the inflammatory agents such as prostaglandins from arachidonic acid. In the present study, EAN showed an inhibition of $62.08 \pm 0.03 \%$ at $100 \mathrm{mg} / \mathrm{ml}$ concentration against the enzyme COX in a dose-dependent manner which is compared with the standard drug diclofenac sodium which showed an inhibition of about $87.49 \pm 0.19 \%$. Figure 3 represents the anti-inflammatory effect of EAN. The EC50 value of extract and diclofenac was found to be $23.28 \mu \mathrm{g} / \mathrm{ml}$ and $12.67 \mu \mathrm{g} / \mathrm{ml}$, respectively.

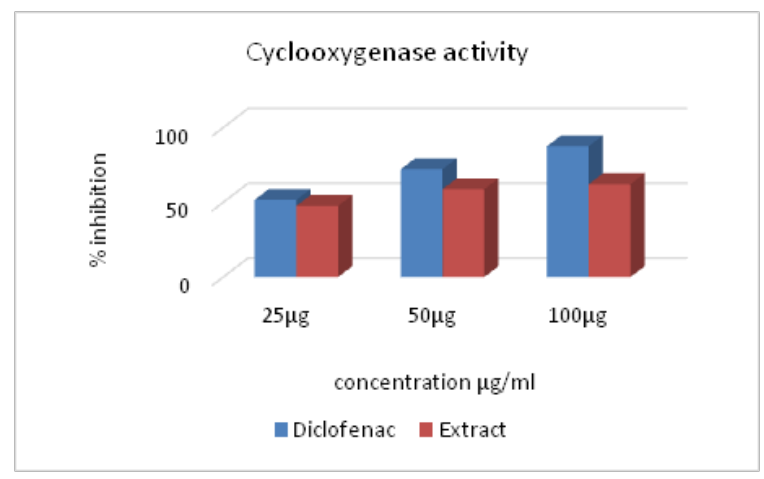

FIGURE 3. Cyclooxygenase activity. 


\subsubsection{LOX Inhibitory Activity}

The EAN exhibited $65.84 \pm 0.19 \%$ inhibition against lipoxygenase activity at $100 \mathrm{mg} /$ $\mathrm{ml}$ concentration thereby blocked the formation of leukotrienes. The dose-dependent inhibition of extract was compared with the standard drug diclofenac sodium which showed an inhibition of $98.20 \pm 0.08 \%$ and EC50 value at $18.16 \mu \mathrm{g} / \mathrm{ml}$. The EC50 value of extract was found to be $20.81 \mu \mathrm{g} / \mathrm{ml}$. The anti-lipoxygenase activity of EAN at varying concentration is shown in Figure 4. The present study indicates the good ability of the extract to reduce the activity of lipoxygenase.

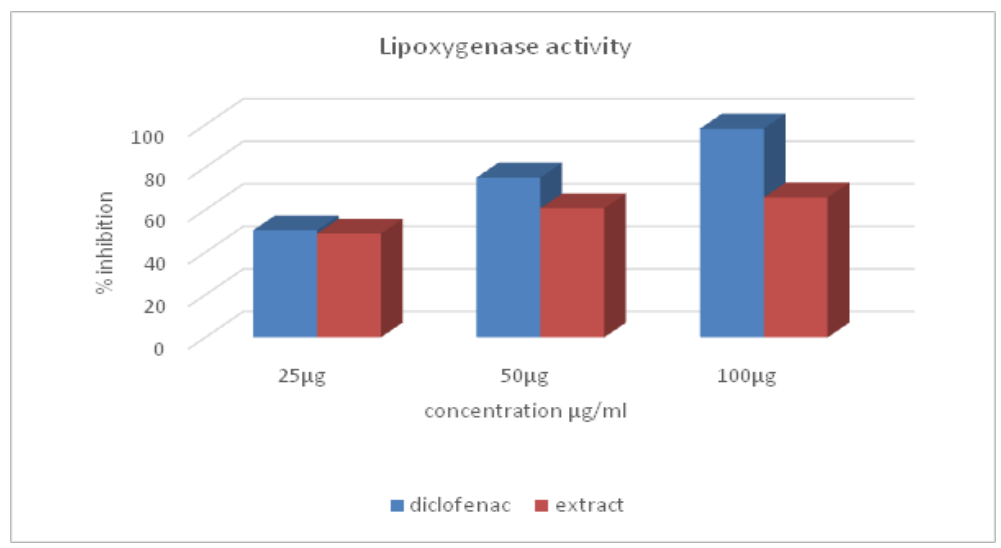

FIGURE 4. Lipoxygenase activity.

\subsubsection{Estimation of $M P O$}

The EAN was found to reduce the enzyme activity to $0.000792 \pm 0.000033 \mathrm{U} / \mathrm{ml}$ and the standard drug diclofenac showed enzyme activity to $0.000481 \pm 0.00006 \mathrm{U} / \mathrm{ml}$ at a concentration of $100 \mu \mathrm{g} / \mathrm{ml}$. The extract reduced the production of MPO in a dosedependent manner, thereby prevented the generation of oxidants. Figure 5 shows the myeloperoxidase inhibitory activity of the extract and the standard drug diclofenac.

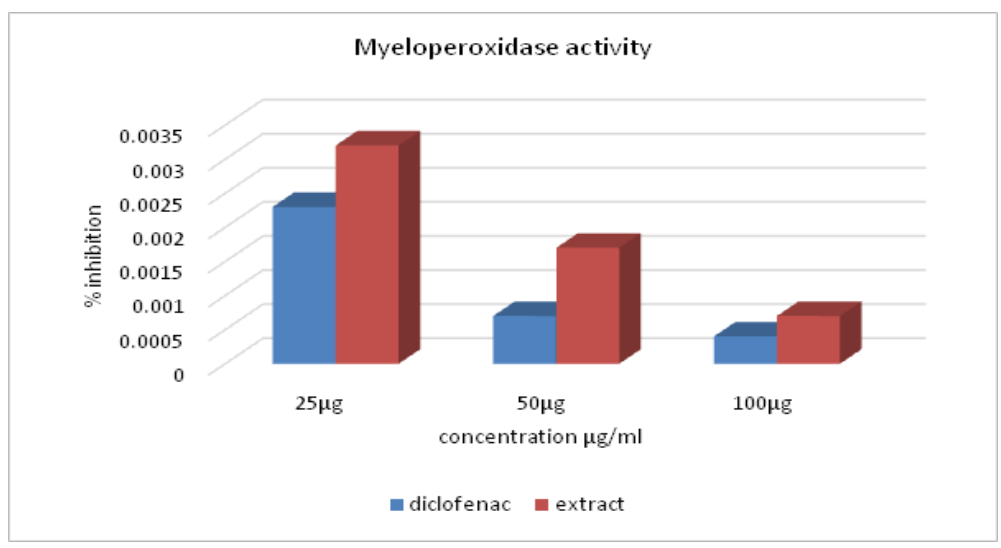

FIGURE 5. Myeloperoxidase activity. 


\subsection{4. iNOS Inhibitory Activity}

iNOS are stimulated in response to inflammatory mediators. The EAN was found to have significant inhibitory effect against iNOS of $90.44 \pm 0.19 \%$ at $100 \mu \mathrm{g}$ concentration which showed an EC50 value of $23.06 \mu \mathrm{g} / \mathrm{ml}$ and the drug diclofenac exhibited an inhibition of $97.4 \pm 0.33 \%$ is shown in Figure 6. The EC50 value of diclofenac was found to be 16.02 $\mu \mathrm{g} / \mathrm{ml}$. The present study indicates that the extract is a potent inhibitor of iNOS in a dosedependent manner.

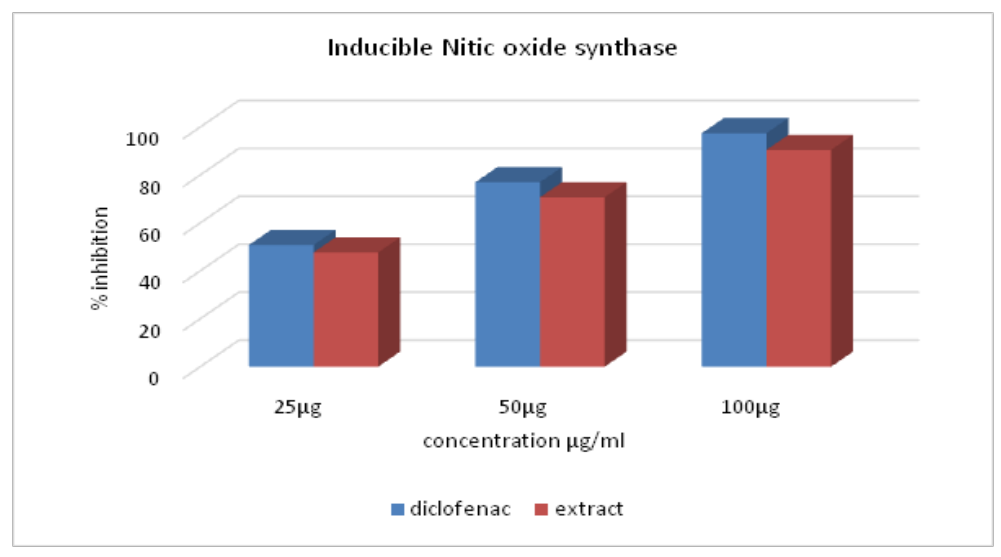

FIGURE 6. Inducible nitric oxide synthase activity.

\subsubsection{Estimation of Cellular Nitrite Level}

The EAN effectively reduced the cellular nitrite at a concentration of $100 \mu \mathrm{g} / \mathrm{ml}$ to $342.54 \pm$ $0.49 \mu \mathrm{g} / \mathrm{ml}$ which is lesser than the standard drug $(339.2 \pm 0.98 \mu \mathrm{g} / \mathrm{ml})$. Figure 7 represents the cellular nitrite level after the treatment with EAN and the drug diclofenac. The EAN exhibited a remarkable ability to reduce the cellular nitrite level.

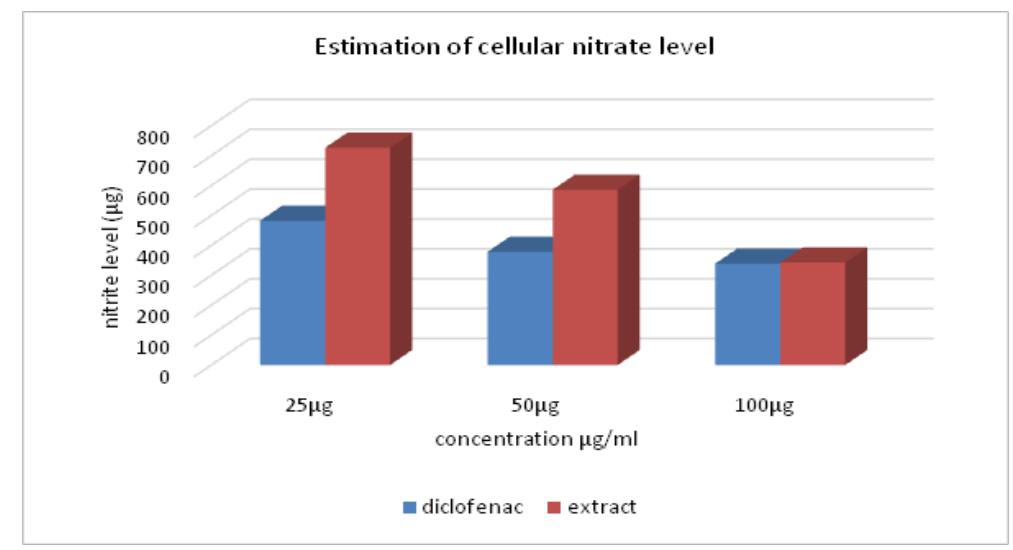

FIGURE 7. Estimation of cellular nitrite level. 


\subsection{GC-MS Analysis}

GC-MS is a powerful tool for identification and determination of phytochemicals. Among the 16 compounds identified, phenol, 2,4-bis(1,1-dimethylethyl) obtained at a retention time of $21.431 \mathrm{~min}$, area of 498345 and area \%- 26.07 is the most prevailing major compound. These phenolic compounds were reported in the literature to have bioactive potential. Other major components include heneicosane, heptadecane, hexatriacontane, tetracosane and $\mathrm{O}$ O'-biphenol, 4,4,6,6'-tetra-t-butyl. The remaining compounds such as undecanol, 1-pentadecane, dodecane ,1-nonadecane, dibutyl phthalate, heptacasanol, eicosane, n-tetracasanol showed the area percentage on and under 5.19. The list of compounds obtained through GCMS were shown in Table 1. The peak obtained through GCMS analysis is shown in Figure 8.

TABLE 1. GCMS analysis of EAN

\begin{tabular}{crrrl}
\hline Peak & R time & Area & Area \% & Name \\
\hline 1 & 4.486 & 59271 & 3.10 & Decane \\
2 & 9.533 & 62091 & 3.25 & 1-Undecane \\
3 & 9.821 & 57622 & 3.01 & Dodecane \\
4 & 17.009 & 99116 & 5.19 & Pentadecene \\
5 & 21.431 & 498345 & 26.09 & Phenol,2,4,bis(1,1-dimethylethyl) \\
6 & 24.776 & 133383 & 6.98 & Heptadecene \\
7 & 32.057 & 83760 & 4.38 & Nonadecene \\
8 & 37.246 & 82644 & 4.32 & Dibutyl phthalate \\
9 & 38.721 & 92534 & 4.84 & 1-Nonadecene \\
10 & 43.435 & 97912 & 5.12 & 1-Heptacosanol \\
11 & 43.534 & 79194 & 4.14 & Eicosane \\
12 & 44.941 & 114546 & 5.99 & Tetracosane \\
13 & 45.515 & 106310 & 5.56 & 0 0'-Bisphenol,4,4',6,6'-tetra-t-butyl \\
14 & 46.053 & 67353 & 3.52 & n-Tetracosanol-1 \\
15 & 46.115 & 152158 & 7.96 & Heneicosane \\
16 & 48.632 & 124993 & 6.54 & Hexatriacontane \\
& & 1911232 & 100.00 & \\
\hline
\end{tabular}

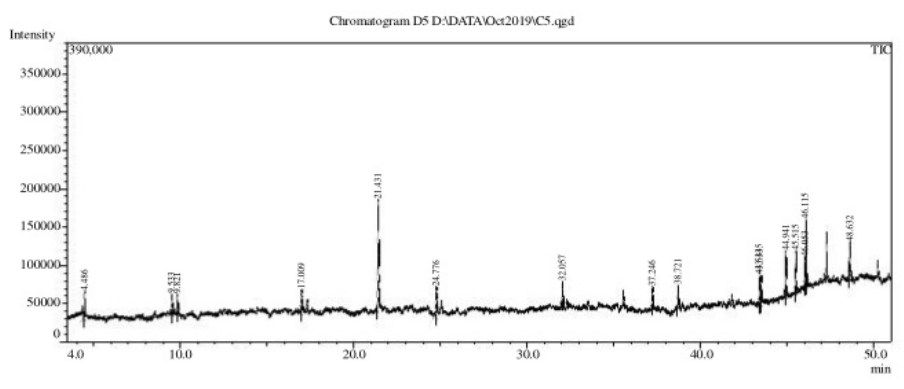

FIGURE 8. GCMS analysis of EAN. 


\section{Discussion}

Inflammation is the defensive response of the body and several mechanisms are involved in it. It is characterized by redness, pain, heat and swelling and leads to loss of function in the injured area. Denaturation of protein and membrane disruption are found to have a role in inflammation. In the present study, initially various extracts of the microalgae, Nannochloropsis sp. were screened for anti-inflammatory activity. Denaturation of proteins was reported to be one of the causes of inflammation [18]. Diseases related to protein denaturation include Alzheimer's, Parkinson's, Huntington's as well as dementia [19]. In the protein denaturation inhibition assay, the EAN exhibited good protection against protein denaturation. There is a resemblance between RBC membrane and lysosomal membrane and so the stabilization activity has the possibility to inhibit content of neutrophils at the site of inflammation [20]. Membrane stabilization assay, the EAN showed significant activity among the various extract. From the membrane stabilization assay, it is confirmed that the EAN can provide cell membrane integrity and viability and thus prevent inflammation. As the EAN exhibited significant activity among the various extracts in the above two mentioned assays, the same was used to evaluate in vitro anti-inflammatory effect in murine macrophage cells. During inflammation, as part of their defensive roles, leukocytes release their lysosomal enzymes, including proteases, causing further tissue damage and subsequent inflammation [21]. The inflamed cells produce pro-inflammatory cytokines as well as stimulate the expression of nitric oxide synthase isoform, iNOS and COX [22]. Leukotrienes are derived from arachidonic acid via lipoxygenase pathway and are involved in the pathogenesis of several inflammatory diseases like asthma, psoriasis, rheumatoid arthritis, and inflammatory bowel diseases [23]. The regulation of this enzyme is important in the inhibition of inflammation and the agents that inhibits these enzymes acts as antiinflammatory agents. The EAN showed significant level of inhibition of pro-inflammatory enzymes such as COX and LOX in a dose-dependent manner. Oxidative stress is a wellknown cause of inflammation. After oxidative stress and different inflammatory responses, MPO enzyme is released into the extracellular fluid which causes several types of tissue injuries and pathogenesis of chronic diseases such as rheumatoid arthritis, cardiovascular diseases, liver diseases, diabetes, and cancer have been reported to be linked with MPOderived oxidants [24]. The antioxidants present in the EAN effectively reduced the oxidants and thereby reduced the MPO production. iNOS produces NO in response to a wide array of stimuli, most prominently endotoxin and endogenous proinflammatory mediator which causes tissue damage during inflammation [25]. The EAN showed remarkable level of inhibition of iNOS as well as cellular nitrite level which were dose dependent. The GCMS study showed the presence of phenols and fatty acid as the major content of the extract which may have role in the anti-inflammatory activity.

\section{Conclusion}

The present study indicates that various extract of Nannochloropsis sp. showed significant anti-inflammatory activity in a dose-dependent manner. Among the various solvent extracts, the EAN exhibited highest protection against protein denaturation and provides 
good stabilization of membranes. The EAN exhibited significant inhibitory activity on enzymes COX and LOX which is indicated by the reduction of cellular nitrite level, inducible nitric oxide synthase and myeloperoxidase, significantly. The phenolic and fatty acid components of the microalgae were identified by GCMS which may be attributing the anti-inflammatory property.

\section{Acknowledgement}

The authors are grateful to Sathyabama University, Centre for Ocean Research, Chennai, Tamil Nadu, India, for the GCMS analysis.

\section{References}

1. Vane CR, Datz S, Dittner PF, Krause HF, Schuch R, Gao H, Hutton R. Electron-positron pair production in Coulomb collisions by 6.4-TeV sulfur ions. Physical Review A. 1994, 50(3), 23132321. https://doi.org/10.1103/PhysRevA.50.2313

2. Kalpa W. Samarakoon, Ju-Young Ko, Md. Mahfuzur Rahman Shah, Ji-Hyeok Lee, Min-Cheol Kang, O-Nam Kwon, Joon-Baek Lee, You-Jin Jeon.In vitro studies of anti-inflammatory and anticancer activities of organic solvent extracts from cultured marine microalgae. Algae. 2013, 28(1), 111-119. http://dx.doi.org/10.4490/algae.2013.28.1.111

3. Seril DN, Liao J, Yang GY, Yang CS. Oxidative stress and ulcerative colitis-associated carcinogenesis: studies in humans and animal models. Carcinogenesis. 2003, 24(3), 353-362. https://doi.org/10.1093/carcin/24.3.353

4. Ramya R, Dhamotharan R. Effect of anti-inflammatory activity of Hellenia speciose (L.) and Costus pictus (L.). World Journal of Pharmacy and Pharmaceutical Sciences. 2017, 6(3), 1009-1017.

5. Amenta R, Camarda I, Di StefanoV, Lentini F, Venza F. Traditional medicine as a source of new therapeutic agents against psoriasis. Fitoterapia. 2000, 71, 13-20. https://doi.org/10.1016/ s0367-326x $(00) 00172-6$

6. Punitha P, Bharathi V. In vitro anti-inflammatory activity in ethanolic extract of Spirulina plantensis and phytochemical analysis underneath GC-MS. World Journal of Pharmaceutical and Medical Research. 2017, 3(11), 217-225.

7. Rajendran V, Lakshmi KS. In vitro and in vivo anti-inflammatory activity of leaves of Sympolocos cochinchinensis (Lour) Moore sub sp. laurina. Bangladesh Journal of Pharmacology. 2008, 3, 121-124. https://doi.org/10.3329/bjp.v3i2.956

8. Mhammed Ben Hafsa, Manel Ben Ismail, MariemGarrab, Raies Aly, Jonathan Gagnon, Karim Naghmouchi. Antimicrobial, antioxidant, cytotoxic and anticholinesterase activities of watersoluble polysaccharides extracted from microalgae Isochrysis galbana and Nannochloropsis oculate. Journal of Serbian Chemical Society. 2017, 82(5), 509-522. https://doi.org/10.2298/JSC161016036B

9. Guiry MD, Guiry GM, Algae Base. World-wide Electronic Publication, National University of Ireland: Galway. http://www.algaebase.org. Date accessed:15/12/2019.

10. Wen ZY, Chen .Heterotrophic production of eicosapentaenoic acid by microalgae. Biotechnology Advances. 2003, 21, 273-294.

11. Tanford C. Protein denaturation. Advanced Protein Chemistry. 1968, 23, 121-282.

12. Oyedepo OO, Femurewa AJ. Antiprotease and membrane stabilizing activities of extracts of Fagra zanthoxiloides, Olax subscorpioides and Tetrapleura tetraptera. International Journal of Pharmacognosy. 1995, 33, 65-69. https://doi.org/10.3109/13880209509088150 
13. Walker MC, Gierse JK. In vitro assays for cyclooxygenase activity and inhibitor characterization. Methods in Molecular Biology. 2010, 644, 131-144. DOI: 10.1007/978-1-59745-364-6_11.

14. Axelrod B, Cheesbrough TM, Laakso S. Lipoxygenases in soybean. In: Methods in enzymology. John M. Lowenstein (ed.), Academic Press: New York. 1981, (71); 441-451. https://naldc.nal. usda.gov/download/23829/PDF

15. Bradley PP, Priebat DA,Christnsen RD, Rothstian G. Measurement of cutaneous inflammation: Estimation of neutrophil content with an enzyme marker. Journal of Investigative Dermatology.1982, 78(3), 206-220. https://doi.org/10.1111/1523-1747.ep12506462

16. Salter M, Duffy C, Garthwaite J, Strijbos PJ. Ex vivo measurement of brain tissue nitrite and nitrate accurately reflects nitric oxide synthase activity in vivo. Journal of Neurochemistry. 1996, 66, 1683-1690. https://doi.org/10.1046/j.1471-4159.1996.66041683.x

17. Lepoivre M, Chenais B, Yapo A, Lemaire G, Thelander L, Tenu JP. Alterations of ribonucleotide reductase activity following induction of the nitrite-generating pathway in adenocarcinoma cells. Journal of Biological Chemistry. 1990, 265(24), 14143-14149. https://www.ncbi.nlm.nih. gov/pubmed/2117605

18. Govindappa M, Naga Sravya S, Poojashri MN, Sadananda TS, Chandrappa CP. Antimicrobial, antioxidant and in vitro anti-inflammatory activity of ethanol extract and active phytochemical screening of Wedelia trilobata (L.) Hitchc. Journal of Pharmacognosy and Phytotherapy. 2011, 3(3), 43-51. https://pdfs.semanticscholar.org/214a/aca7263d4bec682a86e5e542e2fb34908319.pdf

19. Arunkumar G, Bhanumathi K. Pharmaceutical evaluation of enzymatically produced chitooligosaccharides. The Pharma Innovation Journal. 2018, 7(11), 156-161. https:// www.semanticscholar.org/paper/Pharmaceutical-evaluation-of-enzymatically-producedArunkumar-Bhanumathi/2a34b5f6443257879486308c02644aa51de3ba00

20. Reshma, Arun KP, Brindha P. In vitro Anti-Inflammatory, Antioxidant and Nephroprotective studies on leaves of Aegle marmelos and Ocimum sanctum. Asian Journal of Pharmaceutical science and clinical research. 2014, 7(4), 121-129. https://innovareacademics.in/journals/index. php/ajpcr/article/view/2735

21. Kalu Kapuge, Asanka Sanjeewa, Ilekuttige Priyan Shanura Fernando, Kalpa W. Samarakoon, Hetti Handi Chaminda Lakmal, Eun-A Kim, O-Nam Kwon, Matharage Gayani Dilshara, JoonBaek Lee, You-Jin Jeon. Anti-inflammatory and anti-cancer activities of sterol rich fraction of cultured marine microalga Nannochloropsis oculate. Algae. 2016, 31(3), 2777. https://doi. org/10.4490/algae.2016.31.6.29

22. Amri O, Zekhnini A, Bouhaimi A, Tahrouch S, Hatimi A. Anti-inflammatory activity of methanolic extract from Pistacia atlantica Desf. leaves. Pharmacognosy Journal. 2018, 10(1), 71-76.

23. Yosuke Kayama, Tohru Minamino, Haruhiro Toko, Masaya Sakamoto, Ippei Shimizu, Hidehisa Takahashi, Sho Okada, Kaoru Tateno, Junji Moriya, Masataka Yokoyama, Aika Nojima, Michihiro Yoshimura, Kensuke Egashira, Hiroyuki Aburatani, Issei Komuro. Cardiac 12/15 lipoxygenase-induced inflammation is involved in heart failure. The Journal of Experimental Medicine. 2008, 206(7), 1565-1574. https://dx.doi.org/10.1084\%2Fjem.20082596

24. Amjad A Khan, Mohammed A Alsahli, Arshad H Rahmani.Myeloperoxidase as an Active Disease Biomarker: Recent Biochemical and Pathological Perspectives. Medical Sciences (Basel). 2018, 6(2), 33. https://doi.org/10.3390/medsci6020033

25. Philipp Lirk, Georg Hoffmann, Josef Rieder. Inducible nitric oxide synthase - time for reappraisal. Current Drug Targets - Inflammation \& Allergy. 2002, 1, 89-108. https://doi. org/10.2174/1568010023344913 